\title{
Of the Postmodernists' Party Without Knowing It: Philip Pullman, Hypermorality and Metanarratives
}

\author{
Beppie Keane
}

$\mathrm{P}$ hilip Pullman's 'His Dark Materials' trilogy is thematically concerned with resisting existing social codes and practices, particularly those linked with the practice of organized religion. Pullman attempts to establish a secular humanist metanarrative in which he strives to recuperate and valorize mythical Judeo-Christian figures traditionally associated with 'evil'. While secular humanist metanarratives dominate the field of children's and young adult literature, Pullman's version is unique in that it overtly assigns a defining role to the resistance of conservative social practices and thus overtly positions itself in opposition to religious, particularly JudeoChristian, metanarratives (Gooderham 2001 p.157). Ideologically realigning secular humanist texts in blatant opposition to such religious metanarratives is a challenging undertaking, and Pullman's critics have found it not completely successful. This paper agrees that Pullman's 'new' metanarrative does not effectively challenge either Christian or secular humanist metanarratives of the past, and argues that Pullman's portrayal of the concepts of morality, subjectivity and childhood is unstable, vacillating between the implicit acknowledgement of dialogic discourses, and the explicit impulse to resolve these discourses within a monologic perspective. It further suggests that, although he does not manage to establish his 'new' metanarrative as a viable alternative to those of the past, the tension created by this vacillation between the dialogic and the monologic does allow him to destabilize not only the metanarrative that he seeks to subvert, but also the one he attempts to champion. As such, in 'His Dark Materials', Pullman implicitly, and very likely unwittingly, invites his readers to adopt a postmodern 'incredulity toward metanarratives' (Lyotard 1984 p.xxiv).

That Pullman's representations of morality, subjectivity and childhood are unstable becomes more sharply evident if considered from the perspective of George Bataille's concept of hypermorality, with particular reference to the implications that this concept has for subject and agent positions within the text. Hypermorality is a basis for challenging existing moral codes, enabling a revolt against what is accepted as moral and good in order to pass judgment on it. It is not an amoral or nihilist stance, as Bataille is clear that hypermoral actions and judgments require a deep understanding of moral codes (Bataille 1985, pp.22-23). Bataille defines a morally good character, within a Christian society, as one who has a 'strict fidelity to good, based on reason' (Bataille 1985, p.23). A moral action in a society shaped by a Christian humanist metanarrative, then, will require moral agents to have an understanding of what society deems to be good and to use reasoning when confronted with a choice between right and wrong in order to arrive at the decision that conforms to that standard of good. A hypermoral action in the same society occurs when moral agents have a rational understanding of what is deemed to be good, but use their power of reasoning to pass judgment on that standard, often resulting in a choice to do what is deemed as bad or evil within their social environment. That Pullman conforms to Bataille's conceptualization of moral choice as a rational process can be observed in his portrayal of Lyra's moral development in Northern Lights. Early in the text, Pullman's narrator recounts an incident in which Lyra removes some coins from the skulls of dead Jordan College scholars. These coins represent the dæmons of the scholars, a physical manifestation of a human's soul that disappears upon death. At the time, Lyra is unaware of any moral implications that her actions might have, and her repentance of this action is one induced by her fear of night-ghasts, rather than fidelity to a moral code (Pullman 1996, pp.50-51). This contrasts with the later events surrounding the death of Tony Makarios, a boy who, having been severed from his dæmon, clings in death to a piece of dried fish. Lyra is keenly aware of the moral implications of removing this representative of the boy's dæmon; when a man takes the fish away, 'all she saw was right and wrong'(Pullman 1996, p.220). This indicates that she has come to understand the moral significance of such an action. That she proceeds to provide Tony with a dæmon-coin, like those of the Jordan scholars, indicates that she has developed this moral understanding by rationally processing her past experiences (Hines 2005, p.41).

Pullman extends this process of moral reasoning in order to engage readers in a sympathetic hypermoral discourse that challenges some of the dominant moral codes of his protagonists'world, particularly those which are embedded in organized religious institutions, such as the Church of Lyra's world. A recognition of Pullman's recourse to a 
hypermoral discourse enables a clearer judgment about his attempt to establish a secular humanist metanarrative. Pullman's use of his hypermoral discourse as a means of placing himself in clear opposition to religious institutions that 'have always tried to keep [minds] closed' (Pullman 2001, p.506), provides a clear indication as to the nature of his humanist project. Tellingly, the introduction of these institutions in Northern Lights is associated with the suppression of scientifically proven knowledge about other worlds (Pullman 1996, p.31-32). This indicates that in having his protagonists oppose these institutions, Pullman is attempting to legitimate knowledge by suggesting that in his re-created metanarrative,

\section{...humanity [is] the hero of liberty. All peoples have a right to science. If the social subject is not already the subject of scientific knowledge, it is because that has been forbidden by priests and tyrants. \\ (Lyotard 1984, p.31)}

A key facet of this type of metanarrative is that knowledge functions not as something that legitimates itself for its own sake, but as a means of providing humanity with a basis for autonomy, to be guardians unto themselves (Lyotard 1984, p.35). In Pullman's case, this autonomy is symbolized in the Republic of Heaven, which is made possible when the hypermoral quest of the texts, to re-create the Fall, is fulfilled.

The incorporation into the texts, particularly The Amber Spyglass, of a reversion of the Fall of Adam and Eve, in which Lyra, as a latter-day Eve, re-enacts events from the Garden of Eden, highlights another facet of Pullman's use of hypermoral discourse: that these discourses require him to engage strongly and explicitly with traditional Western moral paradigms. In this reversion, Pullman ideologically aligns his texts with the traditionally evil serpent, suggesting that this alignment is a necessary step in passing a negative judgment on religious metanarratives. However, in including a revised Fall in his trilogy, Pullman conforms with a practice observed by Stephens and McCallum, that '...the ground on which traditional narratives are retold or contested is always the Western metaethic' (Stephens and McCallum 1998, p.25). Particularly relevant is the way in which secularized versions of Biblical stories that functioned in their traditional form as narratives on correct social behavior, are framed by structures of authority that were justified in the pre-texts by an assumption of divine authority (Stephens and McCallum 1998, p.25). David Gooderham recognizes that Pullman's substitution of the secular Republic of Heaven for the Christian Kingdom of Heaven overtly suggests to readers that his 'new' metanarrative is distinguished from the old one through its embodiment of 'an emancipatory and "natural" humanism' (Gooderham 2001, p.163). He also suggests, however, that key aspects of Pullman's vision, particularly the social behaviour necessary for the establishment of his emancipated Republic of Heaven, is ultimately 'so entirely uncontentious that no doubt secular humanists, liberal humanists and Christian humanists can all be comfortable with it' (Gooderham 2003, p.173). Gooderham thus demonstrates that, in establishing his 'new' metanarrative of liberty, Pullman's use of traditional structures of authority is only thinly implicit.

Furthermore, the contradiction that exists in his attempt to establish what he presents as a 'new' metanarrative, while framing his texts with traditional structures of authority, is reflected in other aspects of 'His Dark Materials'. AnneMarie Bird, in the first of two articles concerning the way in which the concept of Dust (elementary particles of consciousness) functions metaphorically in 'His Dark Materials', highlights the tension that exists between contrary forces in Pullman's texts, and suggests that the concept of Dust allows for the reconciliation of concepts that seem to be in opposition to each other. She argues that in Dust, which is simultaneously a spiritual and physical substance, Pullman creates a concept that reconciles spirit and matter. Bird argues that this dichotomy symbolically corresponds to traditional Christian conceptualizations of good (spirit) and evil (matter), and as such represents the reconciliation of these opposites (Bird 2001, p.115). In a subsequent study she examines the implications that the concept of Dust has for metanarratives in 'His Dark Materials'. Pullman's explicit and emphatic embrace of a metanarrative that posits humanity as the hero of liberty leads me to disagree with Bird's assertion that Pullman's trilogy ostensibly reflects postmodern antipathy towards modernity (Bird 2005, p.192); any such scepticism towards metanarratives is more deeply implicit within 
the texts than Bird allows. The implicit manifestation of such scepticism in 'His Dark Materials' also suggests a necessary modification of Bird's concluding assertion that Pullman attempts to circumvent the problematic issues that surround his treatment of metanarratives, by placing Dust, a substance that is simultaneously totalizing, functioning as an arbiter of absolute truth, and pluralistic, functioning as an unfixed signifier, at the centre of the trilogy (Bird 2005, pp.196-197). Bird argues that the pluralistic nature of Dust allows Pullman to portray his metanarrative as paradoxically non-totalizing, and asserts that in portraying Dust in this contradictory and unstable way, he circumvents the problematic issues that surround his use of a metanarrative that is framed by traditional structures of authority (Bird 2005, p.197). While this reading of Dust is consistent with Pullman's explicit project to establish a metanarrative that incorporates resistance to conservative social structures as an intrinsic part of it, the tension that it highlights is even more significant when it is read as functioning on a deeply implicit level of Pullman's texts. On this level, the tension created by contradictory forces reveals, not a circumvention of, but a strong engagement with, issues surrounding the legitimation and delegitimation of metanarratives.

The function of hypermorality in Pullman's attempt to establish a 'new' metanarrative provides a key to the deeply implicit level of the trilogy in which Pullman engages with these issues. The concept of hypermorality itself is fraught with tension between seemingly oppositional forces. Of a hypermoral protagonist, Bataille suggests:

He cannot identify with Good because he is fighting it. But even if he is fighting it furiously, he is doing so lucidly: he knows that he represents Good and reason.

(Bataille 1990, p.20)

As such, agents acting hypermorally represent concepts to which they are explicitly opposed, a seeming paradox that is echoed in Pullman's complicity with the metanarrative that he explicitly opposes. The significance of Pullman's utilization of hypermoral discourse is not, however, limited to the explicit narrative of 'His Dark Materials', and its thinly implicit structural adherence to Western religious metanarratives. Rather, the tension created by Pullman's use of hypermoral discourses, reveals the implicit presence of a challenge in Pullman's texts, not only to religious metanarratives, but to all metanarratives.

McCallum's work on the dialogic relationship between agency and subjectivity, particularly with regard to acts of transgression, allows us to better understand the complex relationship between hypermorality and the destabilization of metanarratives in Pullman's trilogy. McCallum points out that 'concepts of personal identity and selfhood are formed in dialogue with society, with language and with other people' (McCallum 1999, p.3). She defines agency as one's ability for deliberate thought and action, and subjectivity as an individual's sense of identity in relation to the discourses of the society (McCallum 1999, p.4). McCallum asserts that humanist, structuralist and poststructuralist arguments all tend to privilege either agent or subject positions by placing them in opposition to each other. Humanism, bound up in the idea of essential selfhood, tends to privilege agency, while structuralism and post-structuralism 'tend to represent the subject as disempowered by the sociolinguistic structures within which it is passively constructed' (McCallum 1999, p.6). McCallum further points out that many theorists feel that this opposition is overcome by means of Bakhtin's concept of dialogism (McCallum 1999, p.6). She defines the dialogic as a relation, or a dialogue, between two positions that does not require them to be oppositional, and therefore irreconcilable; dialectical, synthesizing the two positions into one; or monological, which requires one position to be dominant (McCallum 1999, p.12-13). McCallum is interested in two different ways in which Bakhtin uses the concept of dialogic discourses, but in this paper I focus on one in particular, that which refers to dialogic discourses as existing in relation to monologic discourses. Monologism operates within the context of dialogism, functioning as a snapshot of sociolinguistic discourses, allowing individuals and the texts they produce to suggest that they operate within a unified language system. It is this illusion of a unified language system that allows a fixed representation of agent and subject positions to occur, whereby either individuals acting as agents or the sociolinguistic structures of society is portrayed as being permanently privileged (McCallum 1999, p.13). 
McCallum also follows Bakhtin's argument that the novel is inherently polyphonic, or multivoiced, and labels 'explicitly polyphonic' those novels that use techniques such as multiple narrators or multiple focalizers (McCallum 1999, p.24-25). 'His Dark Materials' then, is explicitly polyphonic, using multiple focalizers that are in turn constituted as multiple voices from different worlds, species and metaphysical planes of existence. Polyphonic narratives allow texts to engage with the concept of intersubjectivity, "the idea that subjectivity exists within interrelationship with others and the world' (McCallum 1999, p.25). Dialogic discourses, which are a facet of polyphony, form a necessary part of the portrayal of intersubjectivity, as they allow individual subjects to be constructed within a social context. McCallum also notes, however, that intersubjective representations of subjectivity can be limited by suppressing dialogic discourses in favour of monologic discourses (McCallum 1999, p.25).

McCallum's discussion of transgression in relation to subjectivity and agency is particularly relevant to Bataille's conceptualization of hypermorality. Hypermoral actions necessarily transgress social codes and practices relating to morality and, due to the dependence of hypermorality upon morality, the relationship between the moral and the hypermoral is one of conflict that cannot be reduced to direct opposition. As such, the relationship between hypermorality and morality is dialogical, correlating to the relationship between agency and subjectivity. McCallum cites White's definition of two categories into which transgressive actions are often placed: one approach, favoured by Bakhtin and Kristeva, leads to the view that transgression is a force that destabilizes social structures, while the other suggests that 'transgressive actions...implicitly reassert the structures they subvert' (McCallum 1999, p.122). Hypermoral transgression, due to its necessary relationship with moral engagement, is difficult to portray as solely destabilizing or implicitly reinforcing existing social structures, as both of these processes are an intrinsic part of any hypermoral action. In instances of hypermoral transgression, therefore, McCallum's suggestion that ' $(t)$ ransgression... might be thought of as a rather tenuous interplay between positions of resistance and complicity', (McCallum 1999, p.122) is particularly relevant. This suggestion also highlights the basis on which individual subjects engaging with the dialogic discourse that exists between hypermorality and morality form intersubjective relationships.

'His Dark Materials' implicitly acknowledges the dialogic relationships existing between agency and subjection, and resistance and complicity, while explicitly articulating these discourses through a monologic humanist narrative. It is in the hypermoral nature of Pullman's challenge to religious metanarratives that this is most apparent. The capacity for Pullman's texts to function hypermorally is readily apparent in that they are sympathetically aligned with Lyra, who must recreate Eve's role in the Fall. Initially, however, the key hypermoral figure of the texts is Lord Asriel. It is Asriel who first challenges not only the Church, but the Authority, or God, who is used as the justification for the Church's power over social and moral codes and practices (Pullman 1998, p.48). Asriel ceases to be a sympathetic figure when he murders Roger at the conclusion of Northern Lights, and this incident cultivates a certain degree of distrust towards his project (Scott 2005, p.98), implying that he is not an ideal candidate to carry Pullman's sympathetic hypermoral discourse. Gooderham argues that Asriel belongs to an outdated theological social construct, and stresses that he is included, with Mrs. Coulter and the Metatron, in the fall into the abyss in The Amber Spyglass, a fall which represents the decline of a Church-dominated metanarrative (Gooderham 2003, pp.163-164). If one accepts that Asriel's inclusion in this incident represents his position in an outdated metanarrative, his hypermoral activities are posited as the type of transgressive act that 'implicitly reassert[s] the structures [it] subvert[s]' (McCallum 1999, p.122). His death symbolizes the rejection of this type of transgressive act, as well as the rejection of the idea that individual subjects are completely disempowered by socio-linguistic structures. This implies that any further hypermoral discourse in the texts will be of the kind that destabilizes social structures. This can be observed in 'His Dark Materials' when, following Asriel's death, Pullman transposes the hypermoral discourse of the texts onto Lyra and Will's quest to re-enact the Fall of Adam and Eve as a positive rather than negative event. The central role that this event has in establishing Pullman's 'new' metanarrative as a replacement for the old one affirms that the hypermoral discourses that are present following Asriel's death are those that destabilize, rather than 
implicitly reassert, social structures. In suggesting that one type of hypermoral transgression replaces another, Pullman implies that hypermorality must function in one of two different monological ways, rather than being part of a dialogic interplay between positions of resistance and complicity.

In spite of this implication, however, Pullman does portray dialogic discourses as being extremely important in his texts, particularly in the interplay between transgression and morality. This is exemplified in the opening chapter of Northern Lights, in which Pullman first introduces the concept of the dæmon. His initial portrayal of Lyra and Pantalaimon as one individual subject seems to imply that he is in accord with McCallum's statement that,

\section{...the concepts of resistance and transgression necessitate a conception of subjectivity as dialogical: individual subjects are simultaneously constrained and empowered by the social and cultural institutions in and through which they are constituted. \\ (McCallum 1999, p.119)}

While the texts suggest that the dæmon represents the soul, the relationship between humans and their dæmons, as portrayed in the opening sequence of Northern Lights, reflects the dialogic agent/subject relationship that exists within the individual subject. Lyra, acting as the agent, is responsible for the moral decision to inform Lord Asriel of the poison in his wine, in addition to making decisions regarding the extent of her transgression of the interdict against unauthorized people, particularly women, entering the retiring room. During this process, Pullman uses Pantalaimon to portray the extent to which she is subject to the social codes and practices of her world: 'Pan,
that wine?'

'Pan, do you really think it's not poison in

'No, 'he said. 'I think it is, like you do. And I think it's none of our business. And I think it would be the silliest thing you've ever done in a lifetime of silly things to interfere. It's nothing to do with us.'

'Don't be stupid, 'Lyra said. 'I can't sit in here and watch them give him poison!'

(Pullman 1996, p.8)
Pantalaimon's encouragement of Lyra not to interfere refers not only to the specific situation with the poisoned wine, but to Lyra's subjective and intersubjective position within her social framework. Lyra's status as a child and female barred from the adult male space of the retiring room allows Pantalaimon to claim 'it's none of our business'. When Lyra does interfere, she establishes herself as an agent, while simultaneously she also forces the part of her nature represented in Pantalaimon to adopt an intersubjective position based on a moral code. Lyra is never free from the social codes and practices that are present in her world, but she is able to use assertions of agency to negotiate her position in relation to those codes and practices.

In addition to being portrayed as capable of moral engagement and intersubjective development, Lyra's transgressive actions are portrayed as operating as a dialogue between resistance towards and complicity with social codes and practices. This capability, combined with the dialogic nature of her transgressive actions, makes Lyra a suitable candidate to carry the hypermoral discourse of the texts after Asriel's demise. It is curious then, that when the time comes for Lyra to fulfill the hypermoral quest of the texts, establishing the conditions of the metanarrative that will allow the Republic of Heaven to be born, the text renders her morally and hypermorally impotent. Readers learn, even before Pullman introduces hypermoral discourses into his texts, that Lyra has an important role to play, but 'that she must do it all without realizing what she's doing' (Pullman 1996, p.32). Ironically, Lyra's ignorance is crucial, even as she (unknowingly) embarks on a quest on behalf of those Pullman names 'the followers of wisdom' (Pullman 2001, p.506), who oppose the Church structures that promote ignorance. Lyra's ignorance stems from Pullman's view of childhood. Pullman believes that childhood is a time of unselfconscious grace, which is lost (or fallen from) at the onset of adolescence (Parsons and Nicholson 1999, p.118). In order for Lyra to metonymically recreate and re-signify the Fall of Genesis, her personal fall from the unselfconscious grace of childhood must be genuine. Pullman engages his readers in a hypermoral discourse, but paradoxically, he legitimates his use of this discourse by portraying it as occurring naturally and ingenuously. 
The transposition of the hypermoral impetus of the text onto Lyra, reveals the problematic nature of this event. In associating Lyra's unknowing fall with a hypermoral action, Pullman contradicts his earlier portrayal of her by implying that her status as a child prevents her from acting as a moral or hypermoral agent. This reveals much about his approach to dialogic discourses, which he acknowledges, while paradoxically attempting to portray them through a monologic humanist narrative, a facet of which is the production of a humanistic essential selfhood. Throughout his texts, Pullman not only portrays subjectivity being formed dialogically through the human/dæmon relationship, but also by stressing the dire consequences should this relationship be severed. Bird notes that individuals who have been severed from their dæmons never possess full subjectivity (Bird 2001,p.118). She also draws attention to Pullman's emphasis upon the unnaturalness of this state of being (Bird 2001, p.117), which he conveys by likening a human severed from their dæmon to,

\section{...someone without a face, or with their ribs laid open and their heart torn out: something unnatural and uncanny that belonged to the world of night- ghasts, not the waking world of sense. \\ (Pullman 1996, p.215)}

An awareness of the dialogic discourses at work in Pullman's texts enables an expansion of Bird's assertion regarding the subjectivity of severed individuals, and suggest that individuals are unable to operate effectively as either a subject or agent once they are denied the possibility of being both simultaneously. The horrific description of a severed human suggests the importance of the dialogic construction of individual subjects. The necessity of this dialogic relationship is also portrayed powerfully in the journey that Lyra and Will take into the world of the dead in The Amber Spyglass. The dæmons of humans cease to exist at the time of death, symbolically representing departure from the social structures of their living worlds. In Pullman's multi-verse however, the individual is forced to continue existing on a hell-like plane without a dialogue between agent and subject, '... a terrible place... it's hopeless, there's no change when you're dead' (Pullman 2001, p.323). When the dead are finally released into a living world, the impossibility of this existence becomes apparent; the shade of the individual's agency dissolves as their dæmon, their sense of self as a subject, did at the time of death.

Pullman devalues the necessity of this relationship, however, just as he devalues Lyra's capacity for moral and hypermoral engagement. In turn, this has the effect noted by McCallum of reducing the potential for intersubjective relationships, and limiting nonsolipsistic interrelationships (McCallum 1999, p.25). Of particular interest is Lyra and Will's estrangement from their dæmons following their journey into the world of the dead. The two children are unable to take their dæmons on this journey, and upon their return remain estranged from each other until after their crucial re-enactment of the Fall. That Lyra and Will are symbolically present only as agents in this instance suggests that they are acting and thinking deliberately, rather than ignorantly or as an instinctive reaction to social codes. By shielding his protagonists from the hypermoral implications of their Fall, however, Pullman restricts their ability to engage in deliberate thought and actions in this instance, problematizing their shift from childhood into adulthood.

This restriction is echoed in Pullman's portrayal of dæmons having a fixed form from the onset of adolescence, implying that at this age subject positions become fixed, and can no longer operate dynamically. After this occurrence, actions requiring agency become spurious, because there is no room for individual subjects to negotiate a new position in relation to the world. Indeed, attempts to do so are designated as a '(w)aste of feeling' (Pullman 1996, p.167). At the onset of adolescence then, in Pullman's worlds, the dialogic relationship between humans and their dæmons is downgraded to a monologic one, in which neither subject nor agent positions can shift in relationship to each other. Intersubjective development is also limited after this occurrence. The dæmons of children are able to change, not only in response to their owner's state of mind, but also in response to the dæmons of others, even settling disputes between children (Pullman 1996, p.269). Because subject positions in adulthood are limited to the fixed form of the dæmon, powerful intersubjective experiences only occur as the result of sexual contact. Will and Lyra's breaking of the taboo against touching each other's dæmons (Pullman 1999, 
p.527-528) is the most obvious example of this occurrence. It is also apparent, however, in the interactions between adult dæmons. Although Pullman specifies that '(d)æmons might touch each other, of course, or fight' (Pullman 1996, p.143), the most marked incidents of two adults' dæmons coming into non-violent contact have clearly sexual overtones. This is apparent when Asriel and Mrs. Coulter meet in Northern Lights (Pullman 1996, p.393-395), and is even more explicit in The Subtle Knife:

'Marisa,' he murmured, 'it's enough of a pleasure to be close to you...'

'No, it isn't, Carlo; you know it isn't. You know I can please you more than this.'

Herdcemon's little black horny hands were stroking the serpent-dcemon. Little by little, the serpent loosened herself and began toflow along the man's arm towards the monkey.

(Pullman 1998, p.324-325)

Mrs. Coulter's (Marisa's) purpose in entering into this exchange is conflict; Carlo does not wish to share some information that she desires. Their dæmons being fixed in form, their potential for intersubjective negotiation is limited to sexual negotiation. As such, although the transition into adulthood is explicitly a time of increased knowledge and experience, the symbolic representation of this transition, the unchanging dæmon, implicitly represents the development of a reduced capability to interact with others. Sexual development, explicitly representing an extension of potential intersubjective relationships in adulthood, implicitly represents the limitations of mature intersubjective interaction.

Pullman, then, inscribes a celebration of adulthood and experience onto the sympathetically produced hypermoral discourse of his texts, but symbolically portrays experienced adult subjects as limited in their ability to develop intersubjectively. This epitomizes the way in which he suppresses dialogic relationships by articulating them through a monologic discourse which explicitly allows him to propagate a metanarrative based on the liberation of humanity. By using a hypermoral discourse as a means of introducing this type of metanarrative, however, Pullman invites a closer consideration of the forces at work in his texts. As a concept that functions dialogically with morality, the presence of a hypermoral discourse, even when the protagonists do not explicitly engage with it at the crucial moment, implicitly reinforces the polyphonic nature of the trilogy. In turn, this could be seen to represent the indeterminate number of language games that, according to Lyotard, intersect to form the fabric of social bonds (Lyotard 1984, p.40). The potential for this intersection of language games in Pullman's texts is vast, extending from the dialogic subject/agent relationship portrayed within individual subjects, to the trans-planar, trans-linguistic communication depicted between Mary Malone and the mulefa.

Lyotard asserts that the absence of a universal metalanguage that transcends all language games disables speculative and humanist processes of legitimation (Lyotard 1984, p.41). Earlier in this discussion, Lyotard highlights the lack of a logical connection between denotative and prescriptive statements:

There is nothing to prove that if a statement describing a real situation is true, it follows that a prescriptive statement based upon it...will be just.

Between 'The door is closed' and 'Open the door' there is no relation of consequence as defined in prepositional logic. The two statements belong to two autonomous sets of rules defining different kinds of relevance, and therefore of competence. (Lyotard 1984, p.40)

The absence of a metalanguage highlights the absence of a universal language game capable of legitimating such prescriptive statements (Lyotard 1984, p.41). Bird's reading of Dust as an arbiter of absolute truth in 'His Dark Materials', 'aiming to unite what is divided in terms of thought, language and culture' (Bird 2005, p.192) allows one to view the substance as Pullman's attempt to portray a metalanguage capable of legitimating prescriptive statements. She also claims that Dust is ineffective as a unifying substance because it cannot avoid the tension that exists between what are conventionally conceptual opposites (Bird 2005, p.195), but she only refers to a seemingly postmodern 'shifting field of relations' (Bird 2005 , p.197) that is present within Dust as a facet of the 
concept's ineffectiveness as a unifying substance, rather than suggesting that these shifting relations could form the basis for an alternative reading of the concept. Bird's reading of Dust can be used to demonstrate that the concept functions ineffectively as a metalanguage, but extending this reading by engaging with the text's dialogic discourses allows Dust to be viewed as a substance that embodies, not simply a metalanguage, but a metadialogue. When Pullman attempts to articulate the results of his hypermoral project through a monologic discourse, the function of Dust is limited to a unifying metalanguage that legitimates prescriptive statements, particularly those regarding moral actions. However, even as he portrays the concept in this way, Pullman is unable to suppress the dialogic nature of Dust completely:

'Understand this,' said Xaphania: 'Dust is not a constant. There's not a fixed quantity that has always been the same. Conscious beings make Dust - they renew it all the time, but thinking and feeling and reflecting, by gaining wisdom and passing it on.

'And if you help everyone else in your worlds to do
that, by helping them tolearn and understand about
themselves and each other and the way everything
works, and by showing them how to be kind instead
of cruel, and patient instead of hasty, and cheerful
instead of surly, and above all how to keep their
minds open and free and curious... Then they will
renew enough to replace what is lost...'
(Pullman 2001, p.520)

The presence of Dust ostensibly legitimates Xaphania's prescriptive statement regarding correct behaviour for conscious beings. Nonetheless, the relationship between conscious beings and Dust is a symbiotic one; although humans and mulefa need Dust, Dust also needs those beings to engage consciously with their surroundings. This process reflects the dialogic discourses that are present in agent/subjectrelationships, and in the relationship between hypermorality and morality, even as it overtly functions as a means of legitimating a monologic discourse. The potential for Dust to engage with dialogic discourses, ultimately emphasizes the impossibility of Dust functioning solely as a metalanguage, unless articulated through monologic discourses that are themselves merely snapshots of a dynamic dialogue. When these dialogic discourses are acknowledged, the 'confusing babble of narratives' (Bird 2005, p.195) present in the multifaceted concept of Dust come to represent a metadialogue that mediates between processes of the legitimation and delegitimation of metanarratives.

The potential for Dust to function as a metadialogue is deeply implicit within 'His Dark Materials'. Explicitly, Pullman uses a monologic discourse to establish a metanarrative in which humanity is the hero of liberty. Although this metanarrative propagates secular humanism, it is framed by traditional structures of authority that originally derive from assumptions about divine authority. In order to portray his metanarrative as being blatantly opposed to metanarratives that are legitimated by such assumptions about divinity, Pullman engages sympathetically with a hypermoral discourse, which allows him to portray resistance to dominant social codes and practices as an intrinsic feature of his 'new' metanarrative. The concept of hypermorality, however, operates not in absolute opposition to, but in a tense dialogue with socially accepted moral codes, and the emphasis that Pullman places upon this concept serves to highlight the presence of dialogic discourses even when articulated through an ostensibly monologic narrative. As such, 'His Dark Materials' vacillates between the monologic and the dialogic, the tension between which affects Pullman's portrayal of morality, subjectivity and childhood. Ultimately, the presence of dialogic discourses in Pullman's texts has an effect that an unapologetic secular humanist is unlikely to anticipate, in that these discourses open up a dialogue between the legitimation and delegitimation of the very metanarrative that 'His Dark Materials' explicitly espouses.

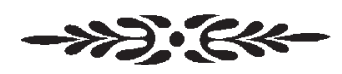

\section{REFERENCES}

Bataille, Georges (1985) Literature and Evil, Trans. A. Hamilton. London, Marion Boyars.

Bird, Anne-Marie (2001) "“Without Contraries is no Progression": Dust as an all-inclusive, multifunctional metaphor in Philip Pullman's 
"His Dark Materials," Children's Literature in Education 32.2: 111-123.

Bird, Anne-Marie (2005) 'Circumventing the Grand Narrative: Dust as an alternate theological vision in Pullman's "His Dark Materials," in Millicent Lenz and Carole Scott (eds) His Dark Materials Illuminated. Detroit, Wayne State University Press, pp.188-198.

Gooderham, David (2003) Fantasizing As It Is: Religious language in Philip Pullman's "His Dark Materials" trilogy, Children's Literature 31: 155-175.

Hines, Maude (2005) 'Second Nature: Dæmons and ideology in The Golden Compass,' in Millicent Lenz and Carole Scott (eds) His Dark Materials Illuminated. Detroit, Wayne State University Press, pp.37-47.

Lyotard, Jean-François (1984) The Postmodern Condition: A Report on Knowledge, Trans. G. Bennington and B. Massumi. Manchester, Manchester University Press.

McCallum, Robyn (1999) Ideologies of Identity in Adolescent Fiction: The Dialogic Construction of Subjectivity. New York, Garland.

Parsons, Wendy and Catriona Nicholson (1999) 'Talking to Philip Pullman: An interview.' The Lion and the Unicorn 23. 1: 116-134.
Pullman, Philip (1996) Northern Lights. London, Scholastic.

Pullman, Philip (1998) The Subtle Knife. London, Scholastic.

Pullman, Philip (2001) The Amber Spyglass. London, Scholastic.

Scott, Carole (2005) 'Pullman's Enigmatic Ontology: revamping old traditions in "His Dark Materials,", in Millicent Lenz and Carole Scott (eds) His Dark Materials Illuminated. Detroit, Wayne State University Press, pp. 95-105.

Stephens, John and Robyn McCallum (1998) Retelling Stories, Framing Culture: Traditional Story and Metanarratives in Children's Literature. New York, Garland.

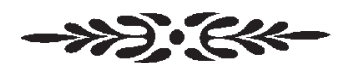

\section{BIOGRAPHICAL NOTE}

Beppie Keane is a PhD student at Macquarie University, Sydney, working under the supervision of John Stephens and Robyn McCallum. Her research focuses on the construction of the concept of 'evil' in fantasy literature for young adults, and she is particularly interested in the work of Philip Pullman, William Nicholson and Ursula le Guin. 